A Journal of Culture, English Language, Teaching \& Literature ISSN 1414-3320 (Print), ISSN 2502-4914 (Online)

Vol. 18 No.2; December 2018

Copyright $\odot$ Soegijapranata Catholic University, Indonesia

From Picture to Text: the Use of Picture in ELT Writing Class

${ }^{1}$ Ika Apriani Fata, ${ }^{2}$ Syamsul Bahri, and ${ }^{3}$ Muridhal

1,2,3 Department of English Education, Faculty of Teacher

Training and Education, Syiah Kuala University, Aceh, Indonesia

email: ${ }^{1}$ ika.apriani@unsyiah.ac.id; ${ }^{2}$ syb.ina@yahoo.com;

3muridhal@gmail.com

Received: $12-08-2018$

Accepted: 29-10-2018 Published: 25-12-2018 


\title{
From Picture to Text: the Use of Picture in ELT Writing Class
}

\author{
${ }^{1}$ Ika Apriani Fata, ${ }^{2}$ Syamsul Bahri, and ${ }^{3}$ Muridhal \\ 1ika.apriani@unsyiah.ac.id; ²s.bahri@unsyiah.ac.id; \\ 3muridhal@gmail.com \\ ${ }^{1,2,3}$ Department of English Education, Faculty of Teacher \\ Training and Education, Syiah Kuala University, Aceh, \\ Indonesia
}

\begin{abstract}
Having students to produce an organized and neat piece of writing has always been the life-long dream and goal of all EFL teachers. Thus, many studies have been conducted under quantitative study as like experimental research, to fill in this gap this study focused on figuring out the teacher's point of view toward the use of picture as media, what are the target and how are the students' participations toward it based by using qualitative design. The instruments applied are interview, observation and field notes, as triangulation data. One English teacher and $36 \mathrm{EFL}$ learners participated as informants in this research. It turned out that the findings showed that based on interview of the teacher, it is believed that media as alternative to assist teacher in teaching writing. Besides, the teacher seems confident to teach writing by using the picture. Furthermore, the English teacher believed that students developed their writing skill by using picture. Meanwhile, based on observation and field notes, the EFL students seem enthusiast to learn writing especially it is combined with group discussion techniques. As further studies, it is best to look at the students writing assessment process through picture strategies in EFL class.
\end{abstract}

Key words: Media, EFL writing, picture, teacher's perception, belief

Abstrak: Memiliki siswa yang mampu menulis tulisan yang baik dan terstruktur selalu menjadi impian dan tujuan seumur hidup bagi semua guru "English as Foreign Language". Oleh karena itu, telah banyak riset yang dilakukan terkait topik ini dengan pendekatan kuantitatif atau 
298 Celt: A Journal of Culture, English Language Teaching \& Literature, Volume 18, Number 2, December 2018, pp. 297 - 309

metode eksperimental. Untuk mengisi gap ini, maka penelitian ini bertujuan melihat perspektif guru dalam menggunakan gambar untuk mengajar kemahiran menulis, apa target belajar dan bagaimana partisipasi siswa dengan pendekatan studi kualitatif. Instrumennya yaitu, wawancara, observasi dan catatan lapangan, triangulasi pengumpulan data. Satu guru bahasa Inggris dan 36 peserta EFL berpartisipasi sebagai informan dalam penelitian ini. Hasil penelitian ternyata menunjukkan guru menerapkan media gambar sebagai alternatif untuk mengajar ketrampilan menulis. Selain itu, guru percaya bahwa siswa akan mengembangkan keterampilan menulis mereka melahi pemaparan gambar dan media yang sesuai. Ini menyiratkan bahwa penggunaan media terutama gambar harus dipelajari oleh siswa untuk memotivasi dorongan mereka dalam kelas menulis bahasa Inggris. Sara untuk pengembangan studi, sebaiknya di kemudian hari diteliti penilaian proses ketrampilan menulis siswa menggunakan media gambar di kelas bahasa Inggris.

Kata kunci: Media, Pembelajaran bahasa asing, gambar, menulis, pandangan guru, keyakinan.

\section{INTRODUCTION}

The use of picture in teaching English as a foreign language has important role in the teaching and learning process. Pictures can help the students be able to develop some sentences to be a paragraph. In teaching language skill especially writing skill, material and media used by the teacher should stimulate the students' creativity. It is not enough to rely on the textbook. It is urged because there are many types of visual media aids that suggested in teaching language, namely black board, slip, pocket, chart, mocks up, poster, cartoon, puppet, and pictures (Harford \& Baird, 2009).

Writing is an activity that arranges the words into a sentence, sentences into a paragraph, and paragraph into a good text. Thus writing is combination of process and product. The process refers to act of getting ideas and working with it (Linse, 2005). The students have to compose their writing and organize their ideas, so that their writing can be understood by the reader. Many students understand the language but most of the students face the problem in writing skill and writing skill is the biggest challenge for many students (Adas \& Bakir,2013). Writing is a difficult task and there are large numbers of English- 
language Students seems to pose greater problem in writing than other language skill (Hedge, 2005).

There have been many studies on writing skill; Al-Khasawneh (2010) also agrees that learning writing is difficult for students; he states that most students face many obstacles in writing especially in organizing their ideas into a composition. On other hand, Jahin \& Idrees (2012) said that although the EFL university students in Saudi Arabia have spent their works to improve writing skill but the result of their writing achievement is still low. Pictures can make students more imaginative and get many ideas in writing paragraphs (Christine, 2009). It is also supported by Gutiérrez, Puello, \& Galvis, (2015) said that picture can increase students' motivation to improve and practice their writing skills. However, there is yet found a research conducted on teacher's view of teaching EFL writing class through picture media in line with curriculum 2013 In Aceh Indonesia. Thus, this study would fill in this gap. This study is guided by the research question: What is teacher's view on having media applied in teaching writing skill? How do students receive media applied in writing class?

\section{LITERATURE REVIEW}

\section{A. Picture as media in ELT}

Using pictures as media is believed to become a good material in learning English. Furthermore, Andrzejczak, Trainin, \& Poldberg (2005) also suggest that the use of visual media is beneficial because it serves mainly as a motivational entry-point to reading and writing activities.

The procedure of applying picture in classroom shows the better result on students writing (Cahyono, 2009). He states there are six steps to get better result in students' writing by applying the picture. First, distribute and explain the usage of picture. Then, divide the students in some groups by asking to count 1 up to 10 . The purpose of grouping the students is to help the teacher control each student in doing the given tasks. Third, ask the students to write a short descriptive paragraph about the pictures. The following paragraph is given as an example. And then, the teacher asks the students to exchange their writing to other students so it is readable and discussable for them. After that, ask the students to return their classmates' texts to the writers. The last step is the teacher asked all students to submit their work. 
300 Celt: A Journal of Culture, English Language Teaching \& Literature, Volume 18, Number 2, December 2018, pp. 297 - 309

Gutiérrez, et al. (2015) stated that, through pictures the students can pay attention to an object or other matters that they have not seen before and pictures also give the students a large experience, understanding, and increase their achievement in writing skill. Without any pictures, they will get difficult in writing sentences or paragraphs because the students may need optional period of time to express their idea that is appropriate to the topic. It is why picture help students in getting the ideas easily by looking at the pictures.

Mansourzadeh (2014) mentioned that there are several functions of using picture. One of them is to attract students' interest and help them visualize the lesson. Using of visual media has several advantages for teaching and learning in descriptive writing. The advantages are: visual media are beneficial in classroom for many reasons. One example is for crowded classroom during a special demonstration in areas, teacher can use visual media classroom to enlarge dissection and experiments in crowded classroom.

\section{METHODOLOGY}

The research design used in this study is qualitative method. The base of framework employed is Rokni \& Karimi (2013). Relating to the design of this study, Neuman (2007) asserts that, this research is categorized as field research, in which the researcher goes to people, setting, or site in order to describe and observe their behavior, and record them naturally such as events, social activities, attitudes, beliefs, perceptions, thoughts, people in group or individually. In this study, the researcher takes the data from interviews, observation, and field notes. The researcher uses the method of Kvale (2006), in elaborating the data from interview. The field notes guideline adapted from Marshall \& Rossman (2006).

\section{FINDINGS}

The teacher gave her perspective about picture media and the way she implemented picture media in the classroom. Based on the interview, the teacher told that picture is a good media to use in teaching EFL writing class because it can increase students' writing skill and their motivation in learning writing skill. This statement is in line with the one finding study conducted by Rokni \& Karimi (2013) who say that the use of visual elements like picture media is a good and useful way for teaching. 
Figure 1:

Students' Enthusiasm in Writing Class

(source: Muridhal)

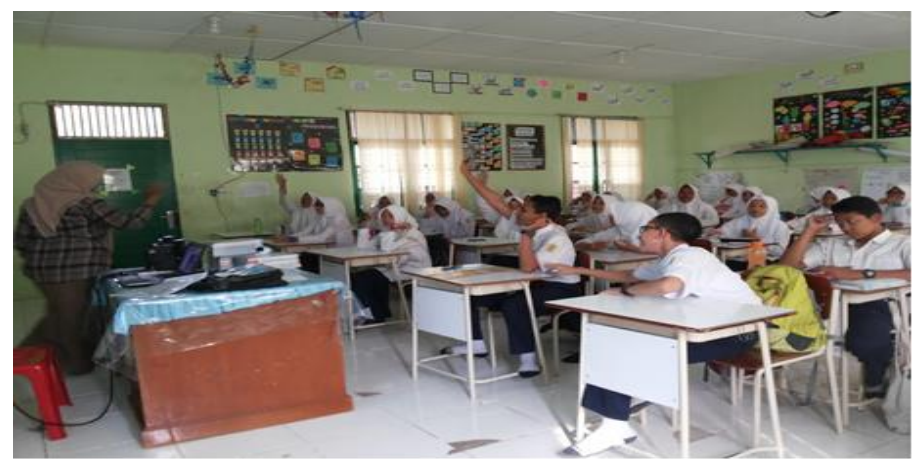

Furthermore, if teachers use visual materials, students' learning atmosphere was getting better than without visual and media. The teacher said that the students seemed surely enthusiast and active in learning writing skill by using picture media.

E1: Question: What is the media that you use to help students in writing skill in accordance with the curriculum 2013? Why?

Teacher's answer: I used picture as media when I taught EFL writing Class, because the students more interested in learning and enthusiast in writing text.

The teacher used picture media in teaching EFL writing class and the students' responses in using picture media were great. Based on the researcher observed the teacher use picture as media to make students observed the object in the picture, it means that the teacher use picture accordance with curriculum 2013. The students are more interested and enthusiast in classroom, it means that the positive atmosphere happened in the classroom by using picture media. This view supported theory by Rokni \& Karimi (2013) that using picture in teaching EFL class attracted the students for better learning. Besides, this data also supported Naseer, Fata, Daud, \& Isniati, (2016) stating that pictures are attractive for students also using pictures help teacher to overcome the problems of translation.

The teacher also told about the references of the picture that she used as media in teaching writing skill. The teacher got the picture from internet, especially in google image by entering the key word. 
302 Celt: A Journal of Culture, English Language Teaching \& Literature, Volume 18, Number 2, December 2018, pp. 297 - 309

E2: Question: Where did you get the picture?

Teacher's answer: I got the picture from google image by using word "picture" as keyword

Based on the data above, we know that the teacher used google image as her references to get the picture. The way she got the picture is by entering the key word in google image. The researcher had checked on google image and he found the picture used by the teacher. Nevertheless, there was a picture that did not appear in the first page of google image. The further question saying about curriculum 2013 as mentioned below.

E3: Question: Does the picture as media that you used is in line with curriculum 2013? Why?

Teacher's answer: Picture as media that I used in line with the demand of curriculum 2013. In curriculum 2013 it is required to study by using picture as media.

Depdiknas (2013) argued that curriculum 2013 emphasizes on modern pedagogical dimensions in learning process, namely adopting scientific approach. Scientific approach used five steps in main activity of learning. Those activities are observing, questioning, associating, experimenting, and networking. The first activity in scientific approach is observing. In this activity, the students observed the objects that learnt by them. The learning activities are reading, listening, and observing. The competence developed is the training of earnestness, precision, for looking information. In this activity the teachers present learning device such as media of learning. In observing activity, the teacher can present the media like a video, picture, miniature, slides, or the real object.

In this study, the teacher uses picture as the media of learning for students in teaching writing. In accordance with researcher observation, the teacher used picture in observing and experimenting activities. Therefore, it can determine that the teacher statement and her teaching activities using picture as media congruent with the curriculum 2013.

E: What are the steps of using picture media in teaching writing?

Teacher's answer: I used power point to display the picture and a text based on picture for students.

E: What will you do if the electricity is off? 

in ELT Writing Class

Teacher's answer: I have another material that I have printed, so I can keep going to teach the students by using picture media.

Based on teacher's statements above, we know that the teacher uses Microsoft power point to display the picture for students. Lari (2014) reported that, the use of technology such as power point can be used as a tool to facilitate teaching and learning. It can promote students' motivation toward learning. This finding is in line with Alkash \& Al-dersi (2013) they argued that teaching and learning of English as a foreign language often poses many difficulties for teachers to present the language instructions. Therefore, the power point can be a helping hand in achieving the goal of language instruction in easy yet powerful way.

It is the undeniable that the use of technology like power point need the electricity, so what does the teacher do if the electricity is off? The teacher also prepared the printed material. So, if the electricity is off, she can continue teaching by using picture as media to teach writing skill. It is in line with the researcher observation; the researcher found that the teacher set up a printed material. Moreover, the teacher also told that the picture media is easy to use in teaching writing skill.

E5: Question: Is picture media easy to use in teaching writing skill? Why?

Teacher's answer: Picture as media is easy to use in teaching writing skill, because when we display the picture to the students they will directly imagine what they see in the picture. For instance, if I display a picture about a cow, they can imagine that the cow has 4 legs and so forth.

The teacher said that using picture as media is easy in teaching writing skill. By using picture as media the students can directly image to describe. It will be easy for students to write a descriptive text. This supported the theory of Yunus, Salehi, \& John (2013) using visual media in teaching is easy and enjoyable. Mansourzadeh (2014) listed several advantages using picture in teaching; "availability, cheapness, flexibility, and variety". It means that the picture media is easy to use.

E6: Question: Can the used of picture media in teaching writing improve students' writing skill? Why? 
304 Celt: A Journal of Culture, English Language Teaching \& Literature, Volume 18, Number 2, December 2018, pp. 297 - 309

Teacher's answer: Students' writing skill increased by using picture media. The students can construct vocabulary by looking at the picture.

In other words, visual material can provide understanding well for students in improving students' writing skill. In regarding to the finding above, the data of interview asserted that the teacher relies on the picture media in teaching writing skill can enhance students' writing skill. The picture can stimulate students to progress of students' vocabulary

In addition, the main point to support the researcher's data, the teacher told that using picture media also can increase students' motivation in learning writing skill. This data also supported the statement of Depdiknas (2013) that one of the goals of the curriculum 2013 in writing skill was that students should able to make a simple text.

E7: Question: Can the picture media improve students' motivation in writing skill?

Teacher's answer: By using picture as media, it can improve students' motivation in learning writing skill. Nowadays the students more interested to visual media such as a picture.

Rokni \& Karimi (2013) agreed that visual materials such as pictures, and real objects, can motivate students for better learning and make the learning process enjoyable and memorable. It is supported by Gutiérrez et al. (2015) who stated that pictures can motivate and help students assimilate their ideas in a way more meaningful and interesting. In addition, picture might encourage students to learn writing ability.

According to the teacher's answer of the interview, she explained the advantages of using picture media in teaching writing skill based on curriculum 2013.

E8: Question: What are the advantages of using picture media in teaching writing skill?

Teacher's answer: advantages of using picture media are, it can improve students' writing skill, and the students can produce vocabulary by using the picture.

Rokni \& Karimi (2013) claimed that using pictures in teaching will help teacher have an interesting class because students are interested in looking at 
the pictures and this way is enjoyable for them. Pictures are attractive for the students.

E9: Question: What were the difficulties that you found when you used the picture media?

Teacher's answer: The difficulty of using picture media is the students are not familiar with the picture that I showed to them sometimes. I need to explain about who is in the picture.

Regarding to the data above, we know that using picture as a media teacher found a problem; however, when the researchers conducting observations the issue is not happened. The teacher had deal with the problem by displaying pictures that have been very familiar to students so that the problem mentioned did not happen.

Prior to start teaching writing using picture media, the teacher reviewed the lesson taught in the last meeting. The teacher showed a picture CR. Ronaldo with a descriptive text about him. The teacher asked the students to observe the picture and to read the text in their mind. This is one of steps of scientific approach in curriculum 2013. Naseer et al. (2016) revealed that in scientific approach the first step is observation. In this step the teacher ask students to observe about the lesson that they learn. They can observe from their environment, video and from the picture. Moreover, the teacher used the picture to be observed by the students.

\section{DISCUSSION}

The teacher asked the students what they thought about the picture. This activity is one of core activities in scientific in approach that call questioning. It means that the teacher using picture as media was in line with curriculum 2013. The teacher asked the question one by one to the students in a whole class. In addition, the teacher asked the students what kind of text it is, the definition of text and the function of text. One of the students raised his hand and answered the question. Ten minutes later, the teacher started to explain about descriptive text, such as the definition of descriptive text, the function, and etc. The teacher explained about descriptive text by using slide presentation. The teacher explained slides one by one to the students and give the students example of CR. Ronaldo picture. Then, the teacher asked the 
306 Celt: A Journal of Culture, English Language Teaching \& Literature, Volume 18, Number 2, December 2018, pp. 297 - 309

students to give example by the one of their friend in their classroom. The teacher mentioned one name and asked students to describe their friend.

After the teacher explained and gave them example, the teacher asked the students to review again about descriptive text in order to know whether they have understood or not about descriptive text. Then the teacher told the students to describe one of their friends in a paper, it could be their classmate or not. Moreover, the teacher gave time to the students about twenty minutes and they should submit their writing to the teacher.

The teacher has provided three images of public figures and famous people in Indonesia and Banda Aceh. There are, the mayor of Banda Aceh Illiza Sa'adudin Djamal, the presenter of program Mata Najwa on Metro TV that is Najwa Sihab and the president of Indonesia Joko Widodo. Then, the teacher called the student's name one by one to select one image that had been provided. Each student got one image. After all students got the picture, the teacher asked them to write a descriptive text based on the picture they got. The teacher gave them about thirty minutes and they should submit it to the teacher at the end of the lesson.

Mansourzadeh (2014), Gutiérrez et.al. (2015) and Rokni \& Karimi (2013) revealed that pictures are those kinds of visual instruction materials can be used in teaching and learning language skill. The findings of this study supported those theories of the benefits using picture media in teaching writing skill for students. In teaching writing skill picture media can increase students' achievements.

Based on teacher's interview it is evidenced that told the teacher used picture media in teaching writing, because the students are more interested and motivated in language learning. This finding is in line with Rokni \& Karimi (2013) that using visual material like picture as media in teaching language skill has positive result. In other words, it can improve students' achievement. In addition, the teacher, surely believes that picture media can improve students writing skill and help students get the idea and vocabulary by using picture media. This supported the theory of Carpenter \& Olson (2011) who examined the effect of teaching new vocabularies through pictures, and their results showed that both the teacher and students who took part in this study had positive attitudes towards using the pictures.

According to Depdiknas (2013) that curriculum 2013 is adapted scientific approach which used 5 steps in main activity of learning. Those activities are, observing, questioning, associating, experimenting, and 
networking. Teacher's answer from interview, she said that, the picture media that teacher used in line with the demand of curriculum 2013. Based on researcher observation when the teacher taught writing skill, the teacher used picture media in line with scientific approach steps. The teacher used picture as the media in observation activity and experimenting activity. It showed that the teacher's answer when the researcher did interview is relevant with the teacher did when she taught writing and using picture as the media. In other word, she did what she said in interview session. Furthermore, the teacher told that picture media was easy to use in teaching writing and can improve students' motivation. It is evidenced that all of students were enthusiast in learning writing skill by using picture media. Most of students were very active in the classroom and it showed by their response of asking and answering the teacher questions. It means that their motivation in learning writing skill was improved.

\section{CONCLUSION}

From picture to text method is believed a very good way in doing writing for a writing class. The use of picture in teaching writing by the English teacher was found successful. Eventhough, the teacher did not implement all procedures of pictures as media, but in general result of using picture in teaching writing was done well. The teacher using picture as a media in teaching writing skill is in accordance with the demand of the 2013 curriculum because the steps of scientific approach has been applied. It can be concluded that the teacher has a positive view toward the use of pictures in writing skill. Furthermore, based on observation result, it is proven that the teacher provided the colorful picture instead of black/ white and it was distributed to all of students in EFL class. The researcher further suggests that English teacher in EFL class use the picture in teaching writing, especially, in writing descriptive text. The teacher should use big and colorful pictures to attract the students' attention. It is also suggested that look picture as media in teaching English besides writing class.

\section{REFERENCES}

Adas, D., \& Bakir, A. (2013). Writing difficulties and new solutions: Blended learning as an approach to improve writing abilities. International Journal of Humanities and Social Science, 3(9), 254-266. 
308 Celt: A Journal of Culture, English Language Teaching \& Literature, Volume 18, Number 2, December 2018, pp. 297 - 309

Alkash, K. A. M., \& Al-dersi, Z. E. M. (2013). Advantages of using powerpoint presentation in EFL classroom \& the status of its use in Sebha University. International Journal of English Language $\mathcal{E}$ Translation Studies, 1(1), 3-16.

Al-Khasawneh, F. M. S. (2010). Writing for Academic Purpose: Problems faced by Arab Postgraduate Students of the College of Bussiness, UMM. ESP World, 9(2), 1-23.

Andrzejczak, N., Trainin, G., \& Poldberg, M. (2005). From image to text: Using images in the writing process. International Journal of Education $\mathbb{E}^{2}$ the Arts, 6(12), 1-16.

Cahyono, B. Y. (2009). Techniques in teaching EFL writing. Malang: State University of Malang press.

Carpenter, S. K., \& Olson, K. M. (2011). Are pictures good for learning new vocabulary in a foreign language? Only if you think they are not. Journal of Experimental Psychology; Learning, Memory and Cognition, 15(2), 10-21.

Christine, C. W. (2009). Using picture in EFL and ESL classroom. Abu Dhabi: Art press.

Depdiknas. (2013). Kurikulum 2013 untuk Sekolah Menengah Pertama/Madrasah Tsanawiyah [2013 Curriculum for Junior High School/Madrasah Tsanawiyah]. Jakarta: Depdiknas.

Gutiérrez, K. G. C., Puello, M. \& Galvis, L. A. P. (2015). Using pictures series technique to enhance narrative writing among ninth grade students at Institución Educativa Simón Araujo. Canadian Center of Science and Education, 8(5), 45-71.

Harford, H., \& Baird, J. (2009). Cambridge English Lexicon. Cambridge: Cambridge University Press.

Hedge, T. (2005). Resource books for teachers: Writing (2 ${ }^{\text {nd }}$ ed.). New York: Oxford University Press.

Jahin, J. H., \& Idrees, M. W. (2012). EFL major student teachers' writing proficiency and attitudes towards learning English. Umm Al-Qura University Journal of Educational Eु Psychologic Sciences, 4(1), 10-72.

Kvale. (2006). Interviews. London: SAGE Publications. 
Fata, I. A., Bahri, S., \& Muridhal. From Picture to Text: the Use of Picture in ELT Writing Class

Lari, F. S. (2014). The Impact of using power point presentations on students' learning and motivation in secondary schools. Procedia - Social and Behavioral Sciences, 98(3), 1672-1677.

Linse, C. T. (2005). Practical English language teaching: Young learner. (D. Nunan, Ed.). New York: Mc Graw Hill, Inc.

Mansourzadeh, N. (2014). A Comparative Study of teaching vocabulary through pictures and audio-visual Aids to young Iranian EFL Learners. Journal of Elementary Education, 24(1), 47-59.

Marshall, C. \& Rossman G. B. (2006). Designing Qualitative Research. Thousand Oaks: CA: Sage.

Naseer, C., Fata, I. A., Daud, B., \& Isniati. (2016). Figuring the context of contextual teaching and learning (CTL) under 2013 curriculum. Culture, English Language Teaching EO Literature (CELT) Journal, 16(2), 149-162

Neuman, W. L. (2007). Basic of Social Research, Quantitative and Qualitative Aproches ( $2^{\text {nd }}$ ed.). New York: Pearson Education.

Nirmala, Y. (2013). Teaching writing using picture stories as tools at High School Level: The movement from other regulation to self-regulation. Language in India, 13(2), 1-211.

Rokni, S. J. A. \& Karimi, N. (2013). Visual Instruction: An advantage or a disadvantage? What about its effect on EFL learners' vocabulary learning? Asian Journal of Social Sciences $\mathcal{E}$ Humanities, 2(4), 236-243.

Swandi,I. S. B. \& Netto-Shek, J. A. (2017). Teaching writing at the primary levels. Indonesian Journal of Applied Linguistics IJAL, 7(1),1-10

Wyrick, J. (2011). Steps to writing well (11 $1^{\text {th }}$ ed.). Los Angeles: Lachina Publishing.

Yunus, M., Salehi, H., \& John, D. S. (2013). Using visual aids as a motivational tool in enhancing students' interest in reading literary texts 2. Recent Advances in Educational Technologies Texts, 5(1), 114-117. 